\title{
Antimicrobial Dispensing Sans Legitimate Prescription from Community Pharmacies in Lahore, Pakistan: Implications for Antimicrobial Resistance
}

\section{Furqan K Hashmi}

University of the Punjab

Sitaram Khadka ( $\boldsymbol{\sim}$ sitaram.khadka@naihs.edu.np)

Shree Birendra Hospital; Nepalese Army Institute of Health Sciences

Mash'hood Mahmood Khan

University of the Punjab

Saif Ullah Khan

University of the Punjab

Hamid Saeed

University of the Punjab

Muhammad Islam

University of the Punjab

Naveel Atif

Xi'an Jiaotong University

Usman Malik

Xi'an Jiaotong University

Muhammad Fawad Rasool

Bahauddin Zakariya University

Muhammad Majid Aziz

Xi'an Jiaotong University

Zineb Riboua

Georgetown University

Hussaam-ul-Haq Mansoor

University of the Punjab

\section{Research Article}

Keywords: Pharmacies, Anti-Bacterial Agents, Self Medication, Drug Resistance, Bacterial, Prescriptions

Posted Date: February 12th, 2021 
DOl: https://doi.org/10.21203/rs.3.rs-152711/v1

License: (c) (1) This work is licensed under a Creative Commons Attribution 4.0 International License. Read Full License 


\section{Abstract}

Background: The use of antimicrobials and their acquisition from pharmacies without prescription is on the rise in low-and middle-income countries contributing towards the emergence of antimicrobial resistance (AMR). The study aims to determine factors influencing the non-prescription dispensing of antibiotics from community pharmacies and implications in AMR.

Methods: A questionnaire-based cross-sectional survey was conducted from January 2019 to September 2019 in Lahore city of Pakistan. The data were analyzed using a statistical package for social sciences (SPSS) version 22. The association of the knowledge, attitude, and practice with demographic parameters were determined using correlation and chi-square test.

Results: The majority of the respondents were male pharmacists (84.5\%) working as staff pharmacists (45.5\%). Among the respondents, $75.9 \%$ considered AMR as a global health threat, however, $52.1 \%$ facilitated antimicrobial dispensing without prescriptions. Respondents stated that non-prescription antimicrobial dispensing was to make medical consultation easy (42\%) and satisfy the demand of the patients (30.1\%). Yet participants recognized the value of patient education concerning drug interactions $42.6 \%$, culture and sensitivity test $31.5 \%$, and full course of antimicrobials $40.8 \%$. Participants were not agreed to dispense antimicrobials in cold and flu (58.1\%), influenza (57.8\%), abdominal pain (50\%), and fever $(60.7 \%)$. They practiced dispensing in diarrhea (62.2\%), urinary tract infections $(68.1 \%)$, ear infection $(56.9 \%)$, and sore throat (64\%). For qualification with all knowledge variables, a significant association was obtained. For marital status and qualification with practice variables, P-value was found significant.

Conclusion: Interventions should be done to halt these irrational practices which have a negative impact on public health. Educational interventions are required for the public. Strict enforcement of rules and regulations, Drug Sale Rules 2007, and implementation of Pakistan's National Action Plan on AMR is required.

\section{Background}

Antimicrobial resistance (AMR) is one of the greatest threats to public health; responsible for increased morbidity and mortality as well as the increased healthcare costs [1,2]. The World Health Organization (WHO) has recognized the importance of AMR for a long, therefore, in 2001 Global Strategy for Containment of Antimicrobial Resistance has provided a framework of interventions to slow the emergence, and reduce its spread [3]. AMR has been declared as a global emergency, in line with that at the 68th World Health Assembly in May 2015 endorsed a Global Action Plan to combat AMR and control the escalation in the trend [4]. The incidence of AMR is more prevalent in developing countries due to poor enforcement of laws and lack of substantial surveillance systems resulting in a high incidence of resistance [5]. AMR can be attributed to irrational use of antibiotics such as; unnecessary, suboptimal (duration, frequency, indication, dose), and extensive use of broad-spectrum antibiotics [6, 7]. 
In low-and middle-income countries (LMICs) dispensing of antibiotics without prescription is common [8]; as it is a convenient, time saving, and cheap way of obtaining the drugs without physician consultation [9], consequently promoting the irrational practice which has long-term effects on patient's health [10].

Pakistan is the sixth most populous country and is categorized as LMIC with a Human Development Index (HDI) value of 0.560 [11]. The healthcare system of Pakistan is under the constantly increasing burden of communicable- as well as non-communicable diseases and a majority of the healthcare spending is out of pocket $[12,13]$. In this context, the public finds it easy to get their medicines from a local retail drug store or pharmacy without having a legitimate prescription from a medical practitioner. Even antibiotics can be acquired as over the counter (OTC) medicines. A study reported a high number of broad-spectrum antibiotics dispensed through community pharmacies, subsequently leading to AMR [14].

The present study aims to evaluate the dispensing of antimicrobials without prescription and evaluation of the knowledge, attitudes, and practices of community pharmacy staff about the dispensing of antimicrobials sans legitimate prescriptions.

\section{Methodology}

\section{Ethics approval}

The research has been performed in accordance with the Declaration of Helsinki. The ethics approval was granted by the Humans Ethics Committee (HEC) University College of Pharmacy, University of the Punjab, Lahore (No: HEC/UCP/2045-19). Informed consent to participate in the study was obtained from participants.

\section{Study design}

A cross-sectional study was carried out in community pharmacies in Lahore, Pakistan from January 2019 to September 2019, principally targeting antimicrobials dispensing without prescription.

A questionnaire was developed comprising of four sections; demographics of participants, knowledge, attitude, and practices of antibiotic dispensing. The knowledge section was based on the concept of the participants. The attitude section proclaims the thinking of the participant. The practice section presents what the respondents perform. Both attitude and practice sections contained statements on a five-point Liker-Scale $(1=$ strongly disagree to $5=$ strongly agree $)$.

The face and content validity of the questionnaire was carried out by three experts at the university. The reliability analysis yielded a Cronbach alpha value of 0.80 .

\section{Sample size}

Online sample size calculator "Raosoft" was used for calculating sample size with a margin of error $5 \%$ and $\mathrm{Cl}$ 95\%. For 3500 pharmacies in Lahore [15], the sample size was 347 pharmacies. The pharmacies 
were randomly selected and pharmacy staffs engaged in drug dispensing; the manager-pharmacy, staff pharmacist, and dispenser were included.

\section{Data analysis}

Data were analyzed by IBM SPSS version 22. Frequencies and percentages were calculated for the demographic variables. The association of the knowledge, attitude, and practice with demographic parameters were determined using correlation and chi-square test.

\section{Results}

A total of 400 questionnaires were distributed among the community pharmacies out of which 336 were returned (response rate $=84 \%)$. The majority of the study respondents were male pharmacists $84.5 \%(\mathrm{n}=$ 284). About $34.8 \%(n=117)$ had work experience of fewer than 2 years while $20.2 \%(n=68)$ had more than 10 years of experience at community pharmacies. Most of the respondents were staff pharmacist $45.5 \%(n=153)$ whereas $35.7 \%(n=120)$ were managers. Only $18.8 \%(n=63)$ were technicians. Table 1 . 
Table 1

Demographics of the study population $(\mathrm{N}=336)$

\begin{tabular}{|c|c|c|c|}
\hline \multicolumn{2}{|l|}{ Demographics } & \multirow{2}{*}{$\begin{array}{l}\text { Frequency (n) } \\
284\end{array}$} & \multirow{2}{*}{$\begin{array}{l}\text { Percentage (\%) } \\
84.5\end{array}$} \\
\hline Gender & Male & & \\
\hline & Female & 52 & 15.5 \\
\hline \multirow[t]{2}{*}{ Marital Status } & Single & 169 & 50.3 \\
\hline & Married & 167 & 49.7 \\
\hline \multirow[t]{4}{*}{ Age (years) } & $18-27$ & 163 & 48.5 \\
\hline & $28-37$ & 115 & 34.2 \\
\hline & $38-47$ & 46 & 13.7 \\
\hline & $>47$ & 12 & 3.6 \\
\hline \multirow[t]{3}{*}{ Job status } & Manager & 120 & 35.7 \\
\hline & Staff Pharmacist & 153 & 45.5 \\
\hline & Technician & 63 & 18.8 \\
\hline \multirow[t]{4}{*}{ Experience (years) } & $<2$ & 117 & 34.8 \\
\hline & $3-5$ & 70 & 20.8 \\
\hline & $6-10$ & 81 & 24.1 \\
\hline & $>10$ & 68 & 20.2 \\
\hline \multirow[t]{4}{*}{ Qualification } & Intermediate & 87 & 25.9 \\
\hline & Graduate / Master & 45 & 13.4 \\
\hline & Diploma of Pharmacy & 13 & 3.9 \\
\hline & B.Pharm / PharmD & 191 & 56.8 \\
\hline
\end{tabular}

The overall knowledge of the community pharmacy staffs regarding antimicrobials as powerful medicines to fight bacterial infection, prescription-only medicines (PoM) status, the optimal duration of treatment, and pharmacists' advice to patients regarding the use of antimicrobials to strictly adhere to the treatment regimen were evaluated. A majority of participants responded to AMR as a public health problem, given in Table 2 
Table 2

Knowledge of antibiotics ( $\mathrm{N}=336)$

\begin{tabular}{|c|c|c|}
\hline Statements & Options & $n(\%)$ \\
\hline \multirow[t]{5}{*}{ Antibiotics are powerful medicines that help to fight against } & Bacteria & $\begin{array}{l}274 \\
(81.5)\end{array}$ \\
\hline & Virus & $\begin{array}{l}26 \\
(7.7)\end{array}$ \\
\hline & Fungi & $\begin{array}{l}1 \\
(0.3)\end{array}$ \\
\hline & Parasites & $\begin{array}{l}2 \\
(0.6)\end{array}$ \\
\hline & Do not know & $\begin{array}{l}33 \\
(9.8)\end{array}$ \\
\hline \multirow[t]{4}{*}{ In which category antibiotics fall? } & $\begin{array}{l}\text { Over the } \\
\text { counter }\end{array}$ & $\begin{array}{l}24 \\
(7.1)\end{array}$ \\
\hline & $\begin{array}{l}\text { Prescription } \\
\text { only Medicine }\end{array}$ & $\begin{array}{l}252 \\
(75)\end{array}$ \\
\hline & $\begin{array}{l}\text { Controlled } \\
\text { medicine }\end{array}$ & $\begin{array}{l}30 \\
(8.9)\end{array}$ \\
\hline & Do not know & $\begin{array}{l}30 \\
(8.9)\end{array}$ \\
\hline \multirow[t]{5}{*}{ What is the course of duration of antibiotic treatment? } & $\begin{array}{l}\text { Less than } 3 \\
\text { days. }\end{array}$ & $\begin{array}{l}4 \\
(1.1)\end{array}$ \\
\hline & 3 Days & $\begin{array}{l}58 \\
(17.3)\end{array}$ \\
\hline & 5 Days & $\begin{array}{l}154 \\
(45.8)\end{array}$ \\
\hline & 7 Days & $\begin{array}{l}106 \\
(31.5)\end{array}$ \\
\hline & Do not know & $\begin{array}{l}14 \\
(4.2)\end{array}$ \\
\hline \multirow[t]{3}{*}{$\begin{array}{l}\text { In all cases where antibiotics are dispensed, it is essential that patients } \\
\text { be advised about complying with the treatment? }\end{array}$} & Yes & $\begin{array}{l}261 \\
(77.7)\end{array}$ \\
\hline & No & $\begin{array}{l}44 \\
(13.1)\end{array}$ \\
\hline & Do not know & $\begin{array}{l}31 \\
(9.2)\end{array}$ \\
\hline Use of antibiotic is rational in minor ailment / self-limiting diseases? & Yes & $\begin{array}{l}111 \\
(33)\end{array}$ \\
\hline
\end{tabular}




\begin{tabular}{|c|c|c|}
\hline Statements & Options & $\mathrm{n}(\%)$ \\
\hline & No & $\begin{array}{l}194 \\
(57.7)\end{array}$ \\
\hline & Do not know & $\begin{array}{l}31 \\
(9.2)\end{array}$ \\
\hline \multirow[t]{3}{*}{ Antibiotic resistance is an important public health problem. } & Yes & $\begin{array}{l}255 \\
(75.9)\end{array}$ \\
\hline & No & $\begin{array}{l}43 \\
(12.8)\end{array}$ \\
\hline & Do not know & $\begin{array}{l}38 \\
(11.3)\end{array}$ \\
\hline
\end{tabular}

The attitude and practices of community pharmacists towards dispensing of antibiotics were evaluated on a five-point Likert scale ( $1=$ strongly disagree to $5=$ strongly agree). Eight questions were asked to test users' attitudes toward the selling of antibiotics, which are depicted in Tables 3 and 4. 
Table 3

Attitude towards dispensing the antibiotic $(\mathrm{N}=336)$

\begin{tabular}{|c|c|c|c|c|c|}
\hline Statements & $\begin{array}{l}\text { Strongly } \\
\text { Disagree } \\
\mathrm{n}(\%)\end{array}$ & $\begin{array}{l}\text { Disagree } \\
\mathrm{n}(\%)\end{array}$ & $\begin{array}{l}\text { Neutral } \\
\mathrm{n}(\%)\end{array}$ & $\begin{array}{l}\text { Agree } \\
\mathrm{n}(\%)\end{array}$ & $\begin{array}{l}\text { Strongly } \\
\text { Agree } \\
\mathrm{n}(\%)\end{array}$ \\
\hline $\begin{array}{l}\text { Non-prescribed dispensing of antibiotic is a } \\
\text { rational medical practice }\end{array}$ & $\begin{array}{l}125 \\
(37.2)\end{array}$ & $94(28)$ & $\begin{array}{l}35 \\
(10.4)\end{array}$ & $\begin{array}{l}48 \\
(14.3)\end{array}$ & $\begin{array}{l}34 \\
(10.1)\end{array}$ \\
\hline $\begin{array}{l}\text { Antibiotics are sometimes dispensed without } \\
\text { a medical prescription because the patient is } \\
\text { known to have difficulty in obtaining a } \\
\text { medical consultation. }\end{array}$ & $\begin{array}{l}44 \\
(13.1)\end{array}$ & $\begin{array}{l}45 \\
(13.4)\end{array}$ & $\begin{array}{l}62 \\
(18.5)\end{array}$ & $\begin{array}{l}141 \\
(42.0)\end{array}$ & $\begin{array}{l}44 \\
(13.1)\end{array}$ \\
\hline $\begin{array}{l}\text { In case of non-prescribed dispensing, } \\
\text { personal experience is the source of deciding } \\
\text { dosage regimen? }\end{array}$ & $\begin{array}{l}45 \\
(13.4)\end{array}$ & $\begin{array}{l}62 \\
(18.5)\end{array}$ & $\begin{array}{l}60 \\
(17.9)\end{array}$ & $\begin{array}{l}124 \\
(36.9)\end{array}$ & $\begin{array}{l}45 \\
(13.4)\end{array}$ \\
\hline $\begin{array}{l}\text { Antibiotic resistance is getting worse and it is } \\
\text { only getting worse. There is nothing I can do. }\end{array}$ & $\begin{array}{l}47 \\
(14.0)\end{array}$ & $\begin{array}{l}81 \\
(24.1)\end{array}$ & $\begin{array}{l}65 \\
(19.3)\end{array}$ & $\begin{array}{l}75 \\
(22.3)\end{array}$ & $\begin{array}{l}68 \\
(20.2)\end{array}$ \\
\hline $\begin{array}{l}\text { When dispensing, possible interaction } \\
\text { between the antibiotic and other drugs } \\
\text { should be assessed. }\end{array}$ & $26(7.7)$ & $31(9.2)$ & $\begin{array}{l}63 \\
(18.8)\end{array}$ & $\begin{array}{l}143 \\
(42.6)\end{array}$ & $\begin{array}{l}73 \\
(21.7)\end{array}$ \\
\hline $\begin{array}{l}\text { Antibiotics are sometimes dispensed even if } \\
\text { not indicated because no time to explain the } \\
\text { reasons. }\end{array}$ & $\begin{array}{l}55 \\
(16.4)\end{array}$ & $\begin{array}{l}70 \\
(20.8)\end{array}$ & $\begin{array}{l}85 \\
(25.3)\end{array}$ & $\begin{array}{l}101 \\
(30.1)\end{array}$ & $25(7.4)$ \\
\hline $\begin{array}{l}\text { There is a need for culture analysis before } \\
\text { dispensing antibiotics in clinically } \\
\text { complicated conditions. }\end{array}$ & $28(8.3)$ & $\begin{array}{l}34 \\
(10.1)\end{array}$ & 64 (19) & $\begin{array}{l}104 \\
(31.0)\end{array}$ & $\begin{array}{l}106 \\
(31.5)\end{array}$ \\
\hline $\begin{array}{l}\text { Completing the course of antibiotic therapy is } \\
\text { crucial in preventing antibiotic resistance. }\end{array}$ & $22(6.5)$ & $24(7.1)$ & $\begin{array}{l}51 \\
(15.2)\end{array}$ & $\begin{array}{l}102 \\
(30.4)\end{array}$ & $\begin{array}{l}137 \\
(40.8)\end{array}$ \\
\hline
\end{tabular}


Table 4

Practice towards antibiotic dispensing $(\mathrm{N}=336)$

\begin{tabular}{|llllll|}
\hline & $\begin{array}{l}\text { Strongly } \\
\text { Disagree } \\
\mathbf{n}(\%)\end{array}$ & $\begin{array}{l}\text { Disagree } \\
\mathbf{n}(\%)\end{array}$ & $\begin{array}{l}\text { Neutral } \\
\mathbf{n}(\%)\end{array}$ & $\begin{array}{l}\text { Agree } \\
\mathbf{n}(\%)\end{array}$ & $\begin{array}{l}\text { Strongly } \\
\text { Agree } \\
\mathbf{n}(\%)\end{array}$ \\
\hline Fever & $116(34.5)$ & $88(26.2)$ & $\begin{array}{l}39 \\
(11.6)\end{array}$ & $68(20.2)$ & $25(7.4)$ \\
\hline Cold and flu & $92(27.4)$ & $\begin{array}{l}103 \\
(30.7)\end{array}$ & $32(9.5)$ & $82(24.4)$ & $27(8)$ \\
\hline $\begin{array}{l}\text { Influenza } \\
\text { Sore throat }\end{array}$ & $104(31)$ & $90(26.8)$ & $\begin{array}{l}52 \\
(15.5)\end{array}$ & $57(17)$ & $33(9.8)$ \\
\hline $\begin{array}{l}\text { Diarrhoea } \\
\text { Abdominal pain }\end{array}$ & $32(9.5)$ & $33(9.8)$ & $\begin{array}{l}56 \\
(16.7)\end{array}$ & $\begin{array}{l}162 \\
(48.2)\end{array}$ & $53(15.8)$ \\
\hline $\begin{array}{l}\text { Otitis media (ear } \\
\text { infection) }\end{array}$ & $30(8.9)$ & $32(9.5)$ & $\begin{array}{l}65 \\
(19.3)\end{array}$ & $131(39)$ & $78(23.2)$ \\
\hline $\begin{array}{l}\text { Urinary tract infection } \\
\text { (UTIs) }\end{array}$ & $29(8.6)$ & $104(31)$ & $\begin{array}{l}83 \\
(24.7)\end{array}$ & $69(20.5)$ & $16(4.8)$ \\
\hline
\end{tabular}

Association of knowledge of antibiotic with demographics was evaluated using correlation and chisquare, given in Table 5 
Table 5

Association of knowledge of antibiotic with demographics

\begin{tabular}{|c|c|c|c|c|c|c|}
\hline STATEMENT & Gender & Age & $\begin{array}{l}\text { Marital } \\
\text { status }\end{array}$ & Job & Experience & Qualification \\
\hline \multirow[t]{2}{*}{ Action of antibiotic } & \multirow{2}{*}{$\begin{array}{l}0.182 \\
(0.001)\end{array}$} & \multirow{2}{*}{$\begin{array}{l}2.089 \\
(0.554)\end{array}$} & \multirow{2}{*}{$\begin{array}{l}-0.049 \\
(0.372)\end{array}$} & \multirow{2}{*}{$\begin{array}{l}-0.102 \\
(0.063)\end{array}$} & \multirow{2}{*}{$\begin{array}{l}-0.151 \\
(0.006)\end{array}$} & 0.454 \\
\hline & & & & & & $(0.000)$ \\
\hline \multirow[t]{2}{*}{ Category of antibiotic } & \multirow{2}{*}{$\begin{array}{l}0.057 \\
(0.297)\end{array}$} & \multirow{2}{*}{$\begin{array}{l}3.795 \\
(0.284)\end{array}$} & \multirow{2}{*}{$\begin{array}{l}0.107 \\
(0.051)\end{array}$} & \multirow{2}{*}{$\begin{array}{l}-0.108 \\
(0.049)\end{array}$} & \multirow{2}{*}{$\begin{array}{l}0.066 \\
(0.227)\end{array}$} & 0.188 \\
\hline & & & & & & $(0.001)$ \\
\hline \multirow{2}{*}{$\begin{array}{l}\text { Duration of antibiotic } \\
\text { treatment }\end{array}$} & \multirow{2}{*}{$\begin{array}{l}0.054 \\
(0.321)\end{array}$} & \multirow{2}{*}{$\begin{array}{l}2.423 \\
(0.489)\end{array}$} & \multirow{2}{*}{$\begin{array}{l}0.096 \\
(0.078)\end{array}$} & \multirow{2}{*}{$\begin{array}{l}-0.088 \\
(0.107)\end{array}$} & -0.009 & 0.166 \\
\hline & & & & & $(0.875)$ & $(0.002)$ \\
\hline \multirow{2}{*}{$\begin{array}{l}\text { Advise the patient for } \\
\text { complying with antibiotic } \\
\text { treatment }\end{array}$} & \multirow{2}{*}{$\begin{array}{l}0.111 \\
(0.042)\end{array}$} & \multirow{2}{*}{$\begin{array}{l}11.633 \\
(0.009)\end{array}$} & \multirow{2}{*}{$\begin{array}{l}-0.210 \\
(0.000)\end{array}$} & \multirow{2}{*}{$\begin{array}{l}-0.067 \\
(0.221)\end{array}$} & \multirow{2}{*}{$\begin{array}{l}-0.179 \\
(0.001)\end{array}$} & 0.183 \\
\hline & & & & & & $(0.001)$ \\
\hline \multirow{2}{*}{$\begin{array}{l}\text { Use of antibiotic; minor } \\
\text { ailment / self-limiting } \\
\text { diseases? }\end{array}$} & \multirow{2}{*}{$\begin{array}{l}0.116 \\
(0.033)\end{array}$} & \multirow{2}{*}{$\begin{array}{l}2.885 \\
(0.410)\end{array}$} & \multirow{2}{*}{$\begin{array}{l}-0.114 \\
(0.038)\end{array}$} & \multirow{2}{*}{$\begin{array}{l}0.024 \\
(0.656)\end{array}$} & \multirow{2}{*}{$\begin{array}{l}-0.078 \\
(0.156)\end{array}$} & 0.175 \\
\hline & & & & & & $(0.001)$ \\
\hline \multirow{2}{*}{$\begin{array}{l}\text { Antibiotic resistance; } \\
\text { public health problem. }\end{array}$} & \multirow{2}{*}{$\begin{array}{l}0.183 \\
(0.001)\end{array}$} & \multirow{2}{*}{$\begin{array}{l}13.379 \\
(0.004)\end{array}$} & \multirow{2}{*}{$\begin{array}{l}-0.117 \\
(0.001)\end{array}$} & \multirow{2}{*}{$\begin{array}{l}-0.075 \\
(0.170)\end{array}$} & \multirow{2}{*}{$\begin{array}{l}-0.230 \\
(0.000)\end{array}$} & 0.483 \\
\hline & & & & & & $(0.000)$ \\
\hline
\end{tabular}

Table 6 shows the association of attitude towards dispensing of antibiotics with demographic parameters was evaluated, given in Table 6. 
Table 6

Association of attitude towards dispensing antibiotic with demographics

\begin{tabular}{|c|c|c|c|c|c|c|}
\hline STATEMENTS & Gender & Age & $\begin{array}{l}\text { Marital } \\
\text { status }\end{array}$ & Job & Experience & Qualification \\
\hline \multirow{2}{*}{$\begin{array}{l}\text { Non-prescribed dispensing } \\
\text { of antibiotic is rational } \\
\text { medical practice. }\end{array}$} & \multirow{2}{*}{$\begin{array}{l}-0.008 \\
(0.887)\end{array}$} & \multirow{2}{*}{$\begin{array}{l}13.514 \\
(0.333)\end{array}$} & \multirow{2}{*}{$\begin{array}{l}-0.006 \\
(0.916)\end{array}$} & \multirow{2}{*}{$\begin{array}{l}-0.050 \\
(0.364)\end{array}$} & \multirow{2}{*}{$\begin{array}{l}-0.042 \\
(0.446)\end{array}$} & 0.166 \\
\hline & & & & & & $(0.033)$ \\
\hline \multirow{2}{*}{$\begin{array}{l}\text { Patient is known to have } \\
\text { difficulty in obtaining } \\
\text { medical consultation. }\end{array}$} & \multirow{2}{*}{$\begin{array}{l}0.026 \\
(0.638)\end{array}$} & \multirow{2}{*}{$\begin{array}{l}30.002 \\
(0.003)\end{array}$} & \multirow{2}{*}{$\begin{array}{l}0.076 \\
(0.165)\end{array}$} & \multirow{2}{*}{$\begin{array}{l}-0.021 \\
(0.700)\end{array}$} & \multirow{2}{*}{$\begin{array}{l}0.048 \\
(0.384)\end{array}$} & -0.086 \\
\hline & & & & & & $(0.115)$ \\
\hline \multirow{2}{*}{$\begin{array}{l}\text { personal experience; the } \\
\text { source of deciding dosage } \\
\text { regimen }\end{array}$} & \multirow{2}{*}{$\begin{array}{l}0.076 \\
(0.167)\end{array}$} & \multirow{2}{*}{$\begin{array}{l}18.503 \\
(0.101)\end{array}$} & \multirow{2}{*}{$\begin{array}{l}-0.024 \\
(0.655)\end{array}$} & \multirow{2}{*}{$\begin{array}{l}-0.077 \\
(0.158)\end{array}$} & \multirow{2}{*}{$\begin{array}{l}-0.016 \\
(0.776)\end{array}$} & 0.018 \\
\hline & & & & & & $(0.747)$ \\
\hline \multirow{2}{*}{$\begin{array}{l}\text { Antibiotic resistance is } \\
\text { getting worse. }\end{array}$} & \multirow{2}{*}{$\begin{array}{l}-0.156 \\
(0.004)\end{array}$} & \multirow{2}{*}{$\begin{array}{l}23.647 \\
(0.023)\end{array}$} & \multirow{2}{*}{$\begin{array}{l}-0.247 \\
(0.000)\end{array}$} & \multirow{2}{*}{$\begin{array}{l}0.000 \\
(0.995)\end{array}$} & \multirow{2}{*}{$\begin{array}{l}-0.291 \\
(0.000)\end{array}$} & 0.300 \\
\hline & & & & & & $(0.000)$ \\
\hline \multirow{2}{*}{$\begin{array}{l}\text { Possible interaction } \\
\text { between antibiotic and other } \\
\text { drugs. }\end{array}$} & \multirow{2}{*}{$\begin{array}{l}-0.029 \\
(0.590)\end{array}$} & \multirow{2}{*}{$\begin{array}{l}17.949 \\
(0.117)\end{array}$} & \multirow{2}{*}{$\begin{array}{l}0.059 \\
(0.281)\end{array}$} & \multirow{2}{*}{$\begin{array}{l}0.000 \\
(0.997)\end{array}$} & \multirow{2}{*}{$\begin{array}{l}0.039 \\
(0.474)\end{array}$} & -0.150 \\
\hline & & & & & & $(0.006)$ \\
\hline \multirow{2}{*}{$\begin{array}{l}\text { Antibiotics are sometimes } \\
\text { dispensed even if not } \\
\text { indicated. }\end{array}$} & \multirow{2}{*}{$\begin{array}{l}0.140 \\
(0.010)\end{array}$} & \multirow{2}{*}{$\begin{array}{l}9.359 \\
(0.672)\end{array}$} & \multirow{2}{*}{$\begin{array}{l}-0.130 \\
(0.017)\end{array}$} & \multirow{2}{*}{$\begin{array}{l}0.079 \\
(0.150)\end{array}$} & \multirow{2}{*}{$\begin{array}{l}-0.049 \\
(0.373)\end{array}$} & 0.051 \\
\hline & & & & & & $(0.347)$ \\
\hline \multirow[t]{2}{*}{ Need of culture analysis } & -0.033 & 15.601 & -0.056 & -0.004 & -0.022 & -0.100 \\
\hline & & & & & & $(0.068)$ \\
\hline Duration of antibiotic & 0.005 & 14.888 & -0.024 & 0.003 & -0.083 & -0.088 \\
\hline $\begin{array}{l}\text { treatment preventing } \\
\text { antibiotic resistance }\end{array}$ & & & & & & $(0.106)$ \\
\hline
\end{tabular}

The association of dispensing behavior of dispensing staff with demographics was evaluated as shown in Table 7. 
Table 7

Association of dispensing behavior of dispensing staff with demographics

\begin{tabular}{|c|c|c|c|c|c|c|}
\hline $\begin{array}{l}\text { Pathological } \\
\text { conditions }\end{array}$ & Gender & Age & $\begin{array}{l}\text { Marital } \\
\text { status }\end{array}$ & Job & Experience & Qualification \\
\hline Fever & $\begin{array}{l}0.177 \\
(0.001)\end{array}$ & $\begin{array}{l}28.730 \\
(0.004)\end{array}$ & $\begin{array}{l}-0.153 \\
(0.005)\end{array}$ & $\begin{array}{l}0.007 \\
(0.898)\end{array}$ & $\begin{array}{l}-0.086 \\
(0.116)\end{array}$ & $\begin{array}{l}0.247 \\
(0.000)\end{array}$ \\
\hline Cold and flu & $\begin{array}{l}0.078 \\
(0.152)\end{array}$ & $\begin{array}{l}12.541 \\
(0.403)\end{array}$ & $\begin{array}{l}-0.193 \\
(0.000)\end{array}$ & $\begin{array}{l}-0.067 \\
(0.223)\end{array}$ & $\begin{array}{l}-0.151 \\
(0.006)\end{array}$ & $\begin{array}{l}0.321 \\
(0.000)\end{array}$ \\
\hline Influenza & $\begin{array}{l}0.116 \\
(0.033)\end{array}$ & $\begin{array}{l}11.590 \\
(0.479)\end{array}$ & $\begin{array}{l}-0.142 \\
(0.009)\end{array}$ & $\begin{array}{l}-0.047 \\
(0.387)\end{array}$ & $\begin{array}{l}-0.070 \\
(0.201)\end{array}$ & $\begin{array}{l}0.269 \\
(0.000)\end{array}$ \\
\hline Sore throat & $\begin{array}{l}0.075 \\
(0.173)\end{array}$ & $\begin{array}{l}29.402 \\
(0.003)\end{array}$ & $\begin{array}{l}-0.139 \\
(0.001)\end{array}$ & $\begin{array}{l}-0.054 \\
(0.325)\end{array}$ & $\begin{array}{l}-0.088 \\
(0.107)\end{array}$ & $\begin{array}{l}0.174 \\
(0.001)\end{array}$ \\
\hline Diarrhea & $\begin{array}{l}0.166 \\
(0.002)\end{array}$ & $\begin{array}{l}19.271 \\
(0.082)\end{array}$ & $\begin{array}{l}-0.070 \\
(0.201)\end{array}$ & $\begin{array}{l}0.010 \\
(0.854)\end{array}$ & $\begin{array}{l}-0.069 \\
(0.204)\end{array}$ & $\begin{array}{l}0.132 \\
(0.016)\end{array}$ \\
\hline Abdominal pain & $\begin{array}{l}0.177 \\
(0.001)\end{array}$ & $\begin{array}{l}22.590 \\
(0.031)\end{array}$ & $\begin{array}{l}-0.161 \\
(0.003)\end{array}$ & $\begin{array}{l}0.102 \\
(0.062)\end{array}$ & $\begin{array}{l}-0.109 \\
(0.046)\end{array}$ & $\begin{array}{l}0.106 \\
(0.051)\end{array}$ \\
\hline $\begin{array}{l}\text { Otitis media (ear } \\
\text { infection) }\end{array}$ & $\begin{array}{l}0.072 \\
(0.191)\end{array}$ & $\begin{array}{l}17.130 \\
(0.145)\end{array}$ & $\begin{array}{l}0.008 \\
(0.881)\end{array}$ & $\begin{array}{l}0.000 \\
(0.996)\end{array}$ & $\begin{array}{l}0.015 \\
(0.790)\end{array}$ & $\begin{array}{l}0.064 \\
(0.243)\end{array}$ \\
\hline $\begin{array}{l}\text { Urinary tract } \\
\text { infection (UTIs) }\end{array}$ & $\begin{array}{l}0.031 \\
(0.576)\end{array}$ & $\begin{array}{l}12.371 \\
(0.416)\end{array}$ & $\begin{array}{l}-0.023 \\
(0.670)\end{array}$ & $\begin{array}{l}0.019 \\
(0.734)\end{array}$ & $\begin{array}{l}0.060 \\
(0.277)\end{array}$ & $\begin{array}{l}-0.011 \\
(0.835)\end{array}$ \\
\hline
\end{tabular}

\section{Discussion}

The destructive properties of AMR are already demonstrating themselves across the globe. With the emergence of resistant strains of bacteria, non-prescribed antibiotic dispensing (NPAD) is also considered a relevant factor to deal with. It imparts a substantial role in the prevalence of AMR globally both in the community and hospital settings [16]. Various studies all over the world presented NPAD with a significant proportion [17-22]. The different studies reported that a majority of pharmacies encountered claims of visitors with self-medication of antibiotics and about half of them dispensed antibiotics without any due requirements $[23,24]$. A similar trend is observed in this study. The results of this study focus on the attributes that lead to NPAD at the community pharmacies.

Out of 336 respondents, most of them were pharmacy graduates (56.8\%) and working either as a manager or staff pharmacist. The majority of the pharmacy staff had an experience of fewer than two years in community pharmacies. Not every pharmacy visited had a pharmacist at that very time, so the place was revisited. The unavailability of a licensed pharmacists in the pharmacy might contribute towards NPAD in a haphazard way and hence AMR.

As far as policy perspective in Pakistan is concerned, the Drug Act 1976/ Drug Regulatory Authority Act 2012 provides the legislative impetus for the sale of medicines only under the supervision of a registered pharmacist $[25,26]$. Despite the act being in place, the sales of antibiotics are poorly regulated because 
of poor enforcement by the concerned authority. In the Punjab province of Pakistan, pertinent rules are formulated for the regulation of drug sales by way of retail; known as the Punjab Drug Rules 2007. These rules have barred the sale of certain drugs without any prescription and have categorized drugs into different schedules viz Schedules B, C, D, E, F, and G. The Schedule-D, permits the sales of drugs strictly on the prescription of a registered medical practitioner [27]. All the antibiotics have been included in this schedule. Therefore, the increasing trend of antimicrobial dispensing without prescription can be attributed to poor enforcement of existing laws in our study setting with a subsequent high rate of AMR.

Knowledge of the participants was good on a marking scale but still, a fair portion (21.1\%) depicted poor knowledge about antibiotic use and dispensing which adds to unnecessary and over-dispensing of antibiotics [28]. Our study revealed that $75 \%$ of the pharmacy staff were well aware of the PoM status of antibiotics. The majority of the respondents $(75.9 \%)$ in this study agreed that AMR is a serious public health problem. However, dispensers supply antibiotics as OTC even after knowing their PoM status. Our study also reveals the same scenario. It is, therefore, necessary that the 'PoM' status of antimicrobials is enforced especially concerning to the sales from community pharmacies, to create an enabling environment for health behavior. A coordinated approach amongst stakeholders, including healthcare workers, patients, and policy-makers on the issue of AMR is needed [29]. The multipronged approach with intra- as well as inter-professional coordination can ensure compliance with the national action plan on AMR.

The difference of opinion is detected among respondents whether to use antibiotics for minor ailments or not. A good portion of participants stated that antibiotics dispensing without prescription renders ease to patients who visit pharmacies and for those who find it difficult to access healthcare facility either due to lack of time or affordability [30]. Different studies across the globe evince a good perception of pharmacy staff regarding the use of antibiotics but still, they do dispense without physician's order without any reluctance [31]. Our findings are found coherent with these facts. Results showed a prominent agreement of proper guidance of patients regarding disease state of the patient, drug interactions, and emphasis on the complete course of antibiotics treatment; which is contradictory to the findings of Asian countries as retrieved by the public opinion about practices of pharmacy staff, especially the pharmacists [32]. About one-third of the respondents stated to dispense antibiotics even in self-limiting and viral infections which is irrational. On average, $60 \%$ of the respondents agreed to provide antibiotics in infectious diseases if the patient gives a direct visit to their pharmacy as soon as the symptoms appear where only symptomatic treatment can bring out relief. The view of respondents in our study coincided with the fact that there is a need for proper laboratory tests for pathogen identification and sensitivity analysis for initiating antibiotics, but their practice of NPAD doesn't match with this. Such practice accounts for irrational use of antibiotics in the community as indicated by National Institute for Health \& Care Excellence (NICE) guidelines [33]. Moreover, guidelines suggest using diagnostic tools for assessing the severity of disease which will eventually reduce over-use of antibiotics and avoid the emergence of AMR [34-36].

Interventions are always a choice for improvement [37]. Good pharmacy practice (GPP) is a landmark standard for achieving rational, cost-effective, and responsible use of medicines to counter abuse of 
antibiotics and halt AMR. In Pakistan, in regards to AMR, the Ministry of National Health Services Regulations \& Coordination Government of Pakistan (MNHSRC) devised a National Action Plan in the year 2017; in which weak curricula of professional education and lack of AMR awareness among professionals are pinpointed as weaknesses of the system [38]. Our findings are in line with the results presented in a study conducted in the physicians of Lahore which, iterate awareness about antibiotics to all the stakeholders of the healthcare profession [39]. Another study in Lahore demonstrated that lowdose and extensive use of broad-spectrum antimicrobials due to ease of access from pharmacies is responsible for high rates of AMR in Pakistan [40]. A study conducted by Saleem et al in Lahore demonstrated that co-amoxiclav, levofloxacin, ciprofloxacin, and third-generation cephalosporins were among the most widely consumed antimicrobials from private healthcare institutions and pharmacies [41]. If the use of such antimicrobials goes unchecked, it results in more resistant strains of microorganisms such as the outbreak of extensively drug-resistant (XDR) Typhoid in Hyderabad, Pakistan in 2016 [42].

According to a broad brush estimate of the global economic cost of antimicrobial drug resistance by 2050, the continually escalated resistance by 2050 will contribute to the death of 10 million people per year. There will be a reduction of 2-3.5\% in Gross Domestic Product (GDP) which would cost the world up to 100 trillion United States Dollar [43].

In this context, the role of health authorities is very important; the Government of Pakistan should prioritize the issue of escalating AMR and formulate its containment strategies, however, there have not been sufficient resources allocated so far for this [44]. Efforts should be made to educate healthcare professionals who deal with drugs such as; pharmacists and physicians regarding the appropriate use of antibiotics to reduce the likelihoods of AMR [45]. Moreover, the pharmacists should be present in the pharmacies and should educate the visitors about self-care and AMR as well. The patients or the public also need to be educated for the use of antibiotics upon prescription by the registered medical practitioner [46].

\section{Strengths And Limitations}

This study signifies the importance of pharmacists and other staff involved in dispensing antimicrobials at community pharmacies. The study setting is the second-largest city in Pakistan, the center of culture, business, and education, and has a structured and well-defined network of pharmacies with the highest number of pharmacists working in the city. This study is limited to only one city in Pakistan. Therefore, the findings of this may not be correlated to the scenario of the whole of Pakistan.

\section{Conclusion}

Lack of enforcement of already existing laws is responsible for extravagant use of antimicrobials sans legitimate prescription and has led to antimicrobial resistance. This demands strict enforcement of the Drug Regulatory Authority of Pakistan Act 2012, Punjab Drug Rules 2007, and Pakistan's National Action 
Plan on antimicrobial resistance. Pharmacy personnel should be trained and aware of dispensing practices as well as the patients should be educated regarding the use of antimicrobials.

\section{Abbreviations}

AMR: Antimicrobial Resistance

DRAP: Drug Regulatory Authority of Pakistan

HDI: Human Development Index

HEC: Humans Ethics Committee

LMICs: Low-and Middle-Income Countries

MNHSRC: Ministry of National Health Services Regulations \& Coordination Government of Pakistan

NICE: National Institute for Health \& Care Excellence

NPAD: Non-Prescribed Antibiotic Dispensing

OTC: Over the Counter

PoM: Prescription only Medicines

WHO: World Health Organization (WHO)

XDR: Extensively Drug Resistant

\section{Declarations}

\section{Ethics approval and consent to participate}

The research has been performed in accordance with the Declaration of Helsinki. The ethics approval was granted by the Humans Ethics Committee (HEC) University College of Pharmacy, University of the Punjab, Lahore (No: HEC/UCP/2045-19). Informed consent to participate in the study was obtained from participants.

\section{Consent for publication}

Not applicable

\section{Availability of data and materials}


The datasets used and/or analysed during the current study available from the corresponding author on reasonable request.

\section{Competing interests}

The authors declare no competing conflict of interest.

\section{Funding}

No funding was obtained from any source.

\section{Authors' contributions}

Furqan K. Hashmi: Conceptualization, Methodology, Formal Analysis, Investigation, Data Curation, and Writing - original draft preparation. Mash'hood Mahmood Khan: Resources, Validation, Investigation, and Project Administration. Saif Ullah Khan: Data Curation. Sitaram Khadka: Methodology, Writing- Reviewing and Editing. Hamid Saeed: Visualization, Writing- Reviewing and Editing. Muhammad Islam: Formal Analysis, Investigation. Naveel Atif: Data curation, Investigation, Writing- Reviewing and Editing. Usman Malik: Investigation, Writing- Reviewing and Editing. Muhammad Fawad Rasool: Supervision. Hussaamul-Haq Mansoor: Formal Analysis. Muhammad Majid Aziz: Validation. Zineb Riboua: Writing- Reviewing and Editing.

\section{Acknowledgements}

We appreciate the help rendered by the Primary and Secondary Health Department, Government of the Punjab, Lahore, Pakistan. We acknowledge the facilitation by the Pakistan Pharmacists Association (Punjab Branch).

\section{References}

1. Boucher HW, Talbot GH, Bradley JS, et al. Bad bugs, no drugs: no ESKAPE! An update from the Infectious Diseases Society of America. Clinical infectious diseases. 2009;48(1):1-12.

2. Prestinaci F, Pezzotti P, Pantosti A. Antimicrobial resistance: a global multifaceted phenomenon. Pathogens global health 2015;109(7):309-318.

3. World Health Organization. WHO global strategy for containment of antimicrobial resistance: World Health Organization; 2001.

4. World Health Organization. Global Action Plan on Antimicrobial Resistance. Available at: https://www.who.int/antimicrobial-resistance/global-action-plan/en/. Accessed 11 July 20202020. 
5. World Health Organization. Antimicrobial resistance global report on surveillance: 2014 summary. World Health Organization; 2014.

6. Tenover FC. Mechanisms of antimicrobial resistance in bacteria. The American journal of medicine. 2006;119(6):S3-S10.

7. Holmes AH, Moore LS, Sundsfjord A, et al. Understanding the mechanisms and drivers of antimicrobial resistance. The Lancet 2016;387(10014):176-187.

8. Alhomoud F, Almahasnah R, Alhomoud FK. "You could lose when you misuse" - factors affecting over-the-counter sale of antibiotics in community pharmacies in Saudi Arabia: a qualitative study. BMC Health Serv Res. Dec 3 2018;18(1):915.

9. Salunkhe S, Pandit V, Dawane J, Sarda K, More C. Study of over the counter sale of antimicrobials in pharmacy outlets in Pune, India: a cross sectional study. Int J Pharm Bio Sci. 2013;4(2):616-622.

10. Auta A, Hadi MA, Oga E, et al. Global access to antibiotics without prescription in community pharmacies: A systematic review and meta-analysis. Journal of Infection. 2019;78(1):8-18.

11. Conceição P. Human Development Report 2019: Beyond Income, Beyond Averages, Beyond Today: Inequalities in Human Development in the 21st Century. United Nations Development Programme; 2019.

12. Kaplan W, Boskovic N, Flanagan D, Lalany S, Lin C-Y. Pharmaceutical policy in countries with developing healthcare systems: synthesis of country case studies. Pharmaceutical Policy in Countries with Developing Healthcare Systems. Springer; 2017:405-430.

13. Atif M, Razzaq W, Mushtaq I, et al. Pharmacy Services beyond the Basics: A Qualitative Study to Explore Perspectives of Pharmacists towards Basic and Enhanced Pharmacy Services in Pakistan. International Journal of Environmental Research Public Health. 2020;17(7):2379.

14. Saleem Z, Hassali MA, Hashmi FK, et al. Evaluating consumption and expenditure patterns of antibiotics in tablet and capsule dosage forms: Pakistan Antibiotic Consumption Surveillance (PACS). Journal of Pharmacy Practice Research 2020;50(1):36-41.

15. Department of Primary and Secondary Health GotP. Pharmacies in Lahore Available at: https://pshealthpunjab.gov.pk/. Accessed 20 July 2020, 2020.

16. Plachouras D, Kavatha D, Antoniadou A, et al. Dispensing of antibiotics without prescription in Greece, 2008: another link in the antibiotic resistance chain. Eurosurveillance. 2010;15(7):19488.

17. Atia $A E$, Abired AN. Antibiotic prescribing for upper respiratory tract infections by Libyan community pharmacists and medical practitioners: An observational study. Libyan Journal of Medical Sciences. 2017;1(2):31.

18. Llor C, Cots JM. The sale of antibiotics without prescription in pharmacies in Catalonia, Spain. Clinical Infectious Diseases. 2009;48(10):1345-1349.

19. Abdelaziz Al, Tawfik AG, Rabie KA, et al. Quality of Community Pharmacy Practice in Antibiotic SelfMedication Encounters: A Simulated Patient Study in Upper Egypt. Antibiotics. 2019;8(2):35. 
20. Al-Faham Z, Habboub G, Takriti F. The sale of antibiotics without prescription in pharmacies in Damascus, Syria. The Journal of Infection in Developing Countries. 2011;5(05):396-399.

21. Morgan DJ, Okeke IN, Laxminarayan R, Perencevich EN, Weisenberg S. Non-prescription antimicrobial use worldwide: a systematic review. The Lancet infectious diseases. 2011;11(9):692701.

22. Amidi S, Ajamee G, Sadeghi H, Yourshalmi P, Gharehjeh A. Dispensing drugs without prescription and treating patients by pharmacy attendants in Shiraz, Iran. American journal of public health. 1978;68(5):495-497.

23. Rabbani F, Cheema F, Talati N, et al. Behind the counter: pharmacies and dispensing patterns of pharmacy attendants in Karachi. JPMA: Journal of the Pakistan Medical Association. 2001;51(4):149.

24. Volpato DE, Souza BVd, Dalla Rosa LG, Melo LH, Daudt CAS, Deboni L. Use of antibiotics without medical prescription. Brazilian Journal of Infectious Diseases. 2005;9(4):288-291.

25. Pakistan Go. Drug Act 1976. Available at: http://www.na.gov.pk/uploads/documents/1493183343_941.pdf. Accessed 13 July 2020, 2020.

26. Pakistan DRAo. DRAP Act 2012 In: Pakistan Go, ed; 2012.

27. Department of Health GoP. Drug Sale Rules 2007 In: Punjab Go, ed; 2007.

28. van Duong D, van Le T, Binns CW. Diarrhoea management by pharmacy staff in retail pharmacies in Hanoi, Vietnam. International Journal of Pharmacy Practice. 1997;5(2):97-100.

29. Shet A, Sundaresan S, Forsberg BC. Pharmacy-based dispensing of antimicrobial agents without prescription in India: appropriateness and cost burden in the private sector. Antimicrobial resistance infection control. 2015;4(1):55.

30. Roque F, Soares S, Breitenfeld L, López-Durán A, Figueiras A, Herdeiro MT. Attitudes of community pharmacists to antibiotic dispensing and microbial resistance: a qualitative study in Portugal. International Journal of Clinical Pharmacy. June 01 2013;35(3):417-424.

31. Erku DA. Antimicrobial stewardship: a cross-sectional survey assessing the perceptions and practices of community pharmacists in Ethiopia. Interdisciplinary perspectives on infectious diseases. 2016;2016.

32. Belkina T, Al Warafi A, Eltom EH, Tadjieva N, Kubena A, Vlcek J. Antibiotic use and knowledge in the community of Yemen, Saudi Arabia, and Uzbekistan. The Journal of Infection in Developing Countries. 2014;8(04):424-429.

33. NICE. Summary of antimicrobial prescribing guidance - managing common infections 2019:23.

34. Little P, Hobbs FR, Moore M, et al. PRImary care Streptococcal Management (PRISM) study: in vitro study, diagnostic cohorts and a pragmatic adaptive randomised controlled trial with nested qualitative study and cost-effectiveness study. Health technology assessment (Winchester, England). 2014;18(6):vii. 
35. Xiao H-l, Ma S-x, Qi H-y, Li X, Wang Y, Yin C-h. A scoring system for assessing the severity of acute diarrhea of adult patients. World journal of emergency medicine. 2016;7(2):130.

36. Hollingworth W, Busby J, Butler CC, et al. The Diagnosis of Urinary Tract Infection in Young Children (DUTY) Study Clinical Rule: Economic Evaluation. Value in Health. 2017;20(4):556-566.

37. Chuc NT, Larsson M, Do NT, Diwan VK, Tomson GB, Falkenberg T. Improving private pharmacy practice: a multi-intervention experiment in Hanoi, Vietnam. Journal of clinical epidemiology. 2002;55(11):1148-1155.

38. Pakistan MoNHSRCGo. Antimicrobial Resistance National Action Plan Pakistan. In: Health Nlo, ed. Vol 1: Government of Pakistan; 2017:64.

39. Saleem Z, Mohamed AH, Hashmi F, et al. Assessment of the perception of physicians concerning antibiotic use and resistance along with the factors influencing the prescription of antibiotics: a situational analysis from Pakistan. Family Medicine Primary Care Review 2019(2):149-157.

40. Saleem Z, Mohamed AH, Hashmi F, et al. Assessment of the perception of physicians concerning antibiotic use and resistance along with the factors influencing the prescription of antibiotics: a situational analysis from Pakistan. Family Medicine Primary Care Review. 2019(2):149-157.

41. Saleem Z, Hassali MA, Hashmi FK, et al. Evaluating consumption and expenditure patterns of antibiotics in tablet and capsule dosage forms: Pakistan Antibiotic Consumption Surveillance (PACS). Journal of Pharmacy Practice Research 2020;50(1):36-41.

42. Andrews JR, Qamar FN, Charles RC, Ryan ET. Extensively drug-resistant typhoid-are conjugate vaccines arriving just in time? New England Journal of Medicine 2018;379(16):1493-1495.

43. Antimicrobial Resistance: Tackling a crisis for the health and wealth of nations. 2014. https://amrreview.org/sites/default/files/AMR Review Paper - Tackling a crisis for the health and wealth of nations_1.pdf

44. Saleem Z, Hassali MA, Hashmi FK. Pakistan's national action plan for antimicrobial resistance: translating ideas into reality. The Lancet infectious diseases 2018;18(10):1066-1067.

45. Saleem Z, Hassali MA, Hashmi F, et al. Medical and pharmacy students' knowledge, attitude and perception concerning antimicrobial use and resistance in Pakistan. Pharmacy Education. 2019;19:199-205.

46. Saleem Z, Hassali MA, Hashmi FK, Godman B, Saleem FJFm, health c. Antimicrobial dispensing practices and determinants of antimicrobial resistance: a qualitative study among community pharmacists in Pakistan. Family medicine community health. 2019;7(3). 